Pace University

DigitalCommons@Pace

2013

\title{
From Peer-to-Peer Networks to Cloud Computing: How Technology Is Redefining Child Pornography Laws
}

Audrey Rogers

Elisabeth Haub School of Law at Pace University

Follow this and additional works at: https://digitalcommons.pace.edu/lawfaculty

Part of the Computer Law Commons, Criminal Law Commons, Internet Law Commons, Juvenile Law Commons, and the Sexuality and the Law Commons

\section{Recommended Citation}

Audrey Rogers, From Peer-to-Peer Networks to Cloud Computing: How Technology Is Redefining Child Pornography Laws, 87 St. John's L. Rev. 1013 (2013), http://digitalcommons.pace.edu/lawfaculty/963/.

This Article is brought to you for free and open access by the School of Law at DigitalCommons@Pace. It has been accepted for inclusion in Pace Law Faculty Publications by an authorized administrator of DigitalCommons@Pace. For more information, please contact dheller2@law.pace.edu. 


\title{
FROM PEER-TO-PEER NETWORKS TO CLOUD COMPUTING: HOW TECHNOLOGY IS REDEFINING CHILD PORNOGRAPHY LAWS
}

\author{
AUDREY ROGERS ${ }^{\dagger}$
}

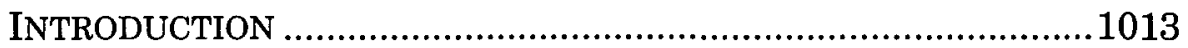

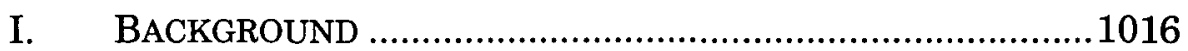

A. Current Law .........................................................1016

B. Legislative and Judicial History .............................1016

C. Sentencing History..................................................1020

D. Current Sentencing Controversy..............................1022

II. THE GROWTH OF TECHNOLOGY.....................................1028

III. THE LINES BLUR..........................................................1033

A. Receiving vs. Possessing ...........................................1033

B. Distributing vs. Possessing.....................................1037

1. Distribution as an Offense..................................1037

2. Distribution as Sentencing Factor .......................1039

C. Transporting vs. Possessing ....................................1041

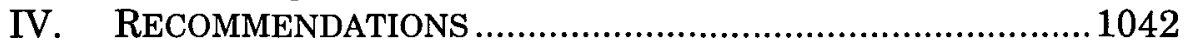

A. The Fundamental Harm in Images..........................1043

B. Statutory and Guideline Changes ..............................1046

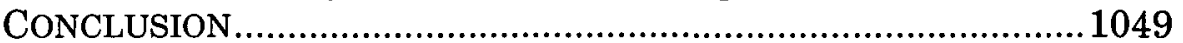

\section{INTRODUCTION}

Congress has aggressively banned activity involving child pornography and has issued numerous directives to the United States Sentencing Commission ("Commission") to increase punishment. As a result, prosecutions and sentences have risen

' Professor of Law, Pace University School of Law. My thanks to Bridget Crawford, Linda Fentiman, and John Furfaro for their comments and support. 
dramatically. ${ }^{1}$ With the demise of mandatory sentencing, ${ }^{2}$ a growing number of district court judges have deviated downward from the sentencing guidelines ("Guidelines"), particularly in possession cases. The debate over the appropriate sentences for convicted child pornographers has also intensified among scholars, judges, legislators, and the general public. Either through judicial rejection of guideline suggestions or through direct action by the Commission, sentencing reform appears likely. ${ }^{3}$ However, the concentrated focus on sentencing overlooks a vital, broader inquiry into the offenses themselves and the changes technology has wrought in how they are committed.

This Article seeks to fill this gap and provide a framework for a normative evaluation of the offenses and their sentences. It contends that laws enacted to address physical world issues of child pornography dissemination are obsolete in the virtual world. It was clear in the late 1970 s, when investigative reporters first exposed the child pornography market, which actors fell into the categories of transporters, distributors, and receivers. ${ }^{4}$ For example, in the past, Suspect Sam would get child pornography from a smut peddler and Suspect Sam's possession of it would not even be a crime. ${ }^{5}$ Today, Suspect Sam most likely gets his child pornography from his home computer

1 Troy Stabenow, Deconstructing THE MYTH OF CaREFul Study: A PRIMER on the Flawed Progression of THE ChILd PoRnography Guidelines 2-3 (2009), available at $\mathrm{http} / / \mathrm{www} . \mathrm{fd}$. org/docs/Select-Topics---sentencing/child-porn-julyrevision.pdf. For example, for one defendant who distributed five images of a child under the age of twelve, the 1987 Guideline range was 12 to 18 months; however, by 2004, the Guideline range was 188 to 235 months. Id. at 27-28. See infra Part I.D for a discussion of the impact of this report.

${ }^{2}$ See United States v. Booker, 543 U.S. 220, 258-60 (2005).

3 The Sentencing Commission recently completed a multiyear review of the child pornography Guidelines that was prompted in large part by changing technology, increased prosecutions, and sentiment that the sentencing scheme was overly harsh. See U.S. SENTENCING COMM'N, REPORT TO THE CONGRESS: FEDERAL CHILD PORNOGRAPHY OFFENSES i-iii (2012) [hereinafter 2012 COMMISSION REPORT], available at http://www.ussc.gov/sites/default/files/pdf/news/congressionaltestimony-and-reports/sex-offense-topics/201212-federal-child-pornography-offenses/ Full_Report_to_Congress.pdf; see also U.S. SENTENCING COMM'N, THE HISTORY OF THE CHILD PORNOGRAPHY GUIDELINES 54 (2009) [hereinafter 2009 COMMISSION REPORT], available at http://www.ussc.gov/Research_and_Statistics/Research_ Projects/Sex_Offenses/20091030_History_Child_Pornography_Guidelines.pdf.

${ }^{4}$ See DEP'T OF JUSTICE, ATTORNEY GENERAL's COMMISSION ON PORNOGRAPHY: FINAL REPORT 599-603 (1986) [hereinafter FINAL REPORT].

${ }^{5}$ See Osborne v. Ohio, 495 U.S. 103, 110-11 (1990) (noting that only nineteen states had banned possession of child pornography in 1990). 
and, by downloading images, he both receives and possesses the images. Current law dictates that Suspect Sam gets a minimum sentence of five years for receiving the images, and up to ten years for possessing them-with no mandatory minimum for the possession. ${ }^{6}$ In addition, simply because he used a computer to commit the offenses, Suspect Sam's sentence would be increased. ${ }^{7}$

To further illustrate the impact of technology, if Suspect Sam downloaded the images from a peer-to-peer application and stored them in a shared online folder, in addition to the receiving and possessing charges, he could also be charged with distributing the images. ${ }^{8}$ These redundancies are not merely sentencing issues; more essentially, there is an overlap in charges since the very same action gives rise to multiple offenses. The once-clear divisions between distribution, transportation, and receipt are blurred in cyberspace. Thus, examining the child pornography statutes is a requisite to addressing current sentencing controversies. Meaningful scrutiny must be grounded in the rationale for the ban on child pornography-the harm to the children depicted.

This Article traces the history of the child pornography laws and sentencing policy in Part I. Part II explains the technologies that have caused some of the current controversies, and then Part III describes how these technologies have blurred the offenses. Finally, Part IV makes suggestions as to how the law could better reflect technology and comport with a refined harm rationale. Courts, legal scholars, and medical experts have explained the harm includes the sexual abuse captured in the images and the psychological injury the victim endures knowing the images are being viewed. This Article further develops the harm rationale by explaining that the harm rests on a fundamental injury to the victim's human dignity and privacy. Drawing on comparisons to diverse laws such as the Geneva Convention's ban on photographs of prisoners of war, this Article states that all traders in child pornography violate the rights of the children depicted, and therefore, inflict harm, albeit at different levels. This Article suggests that a statutory scheme that divides pornographers into three groups-producers, traders, and seekers-would best reflect how technology has

618 U.S.C. $\$ 2252 \mathrm{~A}(2012)$.

7 See infra notes 51-52 and accompanying text.

${ }^{8}$ See infra notes 153,155 and accompanying text. 
changed the manner in which pornography is gathered and spread. Sentences could be calibrated accordingly to punish for the harm inflicted by the pornographers.

\section{BACKGROUND}

\section{A. Current Law}

Federal laws enacted to protect children from child pornographers can be divided into two main categories: First, Congress has enacted a stringent ban on producing child pornography, with a mandatory minimum sentence of fifteen years. ${ }^{9}$ Second, Congress has banned all aspects relating to the trafficking of child pornography, including transporting, distributing, receiving, possessing, accessing, soliciting, or advertising child pornography. ${ }^{10}$ Congress has mandated minimum five-year sentences for transporting, distributing, and receiving, while the other offenses have no minimum sentence. ${ }^{11}$ The following subsection provides a chronology of legislative and judicial action on pornography offenses, with complementary sentencing guidelines. The piecemeal and reactive development of the law demonstrates why deep structural changes are presently needed.

\section{B. Legislative and Judicial History}

Following an increased public awareness of the scourge of child pornography in the late $1970 \mathrm{~s}$, Congress passed the Protection of Children Against Sexual Exploitation Act of 1977. ${ }^{12}$ The Act punished commercial producers, ${ }^{13}$ transporters,

918 U.S.C. $\$ 2251$.

${ }_{10} I d . \$ 2252 \mathrm{~A}$.

${ }^{11} I d$. $\S 2252 \mathrm{~A}(\mathrm{~b})(1)-(2)$. Attempts are punished the same as the completed offenses. Id.

${ }_{12}$ Pub. L. No. 95-225, 92 Stat. 7 (1978) (codified as amended at 18 U.S.C. §§ 2251-2253 (2012)). See generally FINAL REPORT, supra note 4, at 40815; Eva J. KLAIN ET AL., AM. BAR Ass'N CTR. ON CHILDREN \& THE LAW, CHILD PORNOGRAPHY: THE CRIMINAL-JUSTICE-SYSTEM RESPONSE 12 (2001).

${ }_{13}$ Protection of Children Against Sexual Exploitation Act of 1977 \& , 18 U.S.C. $\$ 2251$. The commercial purpose requisite stemmed from an erroneous assumption by Congress that pecuniary gain was the driving force behind the creation and trading of child pornography. See Annemarie J. Mazzone, Comment, United States v. Knox: Protecting Children from Sexual Exploitation Through the Federal Child Pornography Laws, 5 Fordham InTELl. Prop. MEdia \& ENT. L.J. 167, 182-83 (1994). It became clear by the lack of successful prosecutions under the 1977 
distributors, and receivers of obscene child pornography. ${ }^{14}$ During this same time period, states were also enacting their own bans on child pornography without the obscenity requirement. ${ }^{15}$ This led to the 1982 landmark ruling in New York v. Ferber, ${ }^{16}$ in which the United States Supreme Court held that child pornography was not protected by the First Amendment even if it was not obscene because it was "intrinsically related to the sexual abuse of children."17 The Court reasoned that the materials produced were a permanent record of the child's participation and the harm to the child was exacerbated by their circulation. ${ }^{18}$ The Court recognized the dignitary harm inflicted by child pornographers, observing that they violate "the individual interest in avoiding disclosure of personal matters." 19

Following Ferber, Congress amended the original federal child pornography legislation to remove the obscenity and commercial purpose requirements. ${ }^{20}$ Congressional hearings leading to the amendments found that much of the trade between child pornographers was by gift or exchange, so the commercial purpose requirement unnecessarily limited the reach of the law. ${ }^{21}$ Thus, from very early on, Congress was aware purveyors of child pornography were motivated by more than money; ${ }^{22}$ this impulse has been greatly exacerbated by technology. ${ }^{23}$

Act that the commercial purpose limitation was thwarting enforcement efforts. Moreover, future congressional investigation revealed that child pornography rings were a cottage industry among like-minded individuals. Id.; see Audrey Rogers, Protecting Children on the Internet: Mission Impossible?, 61 BAYLOR L. REV. 323, 326-28 (2009).

${ }_{14} 18$ U.S.C. $\$ 2252$. The obscenity requirement was based on congressional fear that the courts would strike the legislation as unconstitutional without it. See Amy Adler, Inverting the First Amendment, 149 U. PA. L. REV. 921, 929-30 (2001).

${ }_{15}$ See Adler, supra note 14, at 930-32.

${ }_{16} 458$ U.S. 747, 773-74 (1982).

17 Id. at 759 .

${ }_{18} I d$.

${ }^{19}$ Id. at 759 n.10 (quoting Whalen v. Roe, 429 U.S. 589, 599 (1977)).

${ }^{20}$ Child Protection Act of 1984, Pub. L. No. 98-292, 98 Stat. 204 (1984) (codified as amended at 18 U.S.C. $\$ \S 2251-2253$ (2012)).

${ }^{21}$ Mazzone, supra note 13 , at 182 . Congress also found the obscenity requirement posed enormous hurdles for prosecutors given the complexity of obscenity rules and standards. Id.

${ }^{22}$ See, e.g., United States v. C.R., 792 F. Supp. 2d 343, 369-70 (E.D.N.Y. 2011).

${ }^{23}$ Id. at 373-74. 
The hearings also revealed that production of child pornography was so clandestine that, between 1978 and 1984, only one person was convicted for producing child pornography.$^{24}$ Thus, the need to stop the flow, rather than the production of child pornography, became the preferred route for prosecutors. The difficulty of reaching producers has not abated as most child pornography is now produced overseas in countries with few or no effective laws against child exploitation. ${ }^{25}$

Originally, there was no federal ban on possessing child pornography in large part because the Supreme Court had previously ruled possession of obscene materials was protected by the First Amendment. ${ }^{26}$ However, in Osborne v. Ohio, ${ }^{27}$ the Court ruled that the mere possession or viewing of child pornography victimized children and the state could prohibit it. ${ }^{28}$ The Osborne Court reiterated that pornography is a permanent record of a victim's abuse that "causes the child victims continuing harm by haunting the children in years to come." ${ }^{29}$ In addition, the Court reasoned that banning possession would protect future victims of child pornography by drying up the market for it. ${ }^{30}$ Congress reacted to Osborne and passed the

${ }^{24}$ See FINAL REPORT, supra note 4, at 604 .

${ }^{25}$ See Int'l Ctr. for Missing \& Exploited Children, Child Pornography: Model Legislation \& Global Review, http://www.icmec.org/missingkids/servlet/PageServlet? LanguageCountry=en_X1\&PageId=4346 (last visited Mar. 2, 2014).

${ }_{26}$ See Stanley v. Georgia, 394 U.S. 557, 568 (1969). The Stanley Court reasoned that prohibiting the possession of obscene materials in one's home was inimical to the very premise of the First Amendment's protection against state interference with what a person thinks, reads, or views in the privacy of his home. Id. at 565-66. It specifically rejected the state's claim that it had a legitimate interest in banning the possession of obscene material because this material may lead to sexual violence. Id. at 566-67. The Stanley Court stated that not only was there no empirical evidence that supported the state's claim, but that crime prevention is better served by "education and punishment for violations of the law" than by criminalizing anticipatory conduct. $I d$. The Stanley Court also rejected the state's contention that criminalizing possession was needed to support the state's ban on the distribution of obscene materials, reasoning that this need did not justify a ban on what a person read or viewed in his home. Id. at 567-68.

27495 U.S. 103 (1990).

${ }^{28}$ Id. at $109-10$ (distinguishing its ruling in Stanley and holding that the state's interest in protecting children by banning possession of child pornography outweighed a defendant's First Amendment rights because of the harm inflicted to children by all involved in the child pornography chain).

${ }^{29} I d$. at 111.

${ }^{30}$ Id. at 109-10. The Osborne Court also added a new prospective rationale for the possession ban: to thwart the use of images to seduce new victims. Id. at 111 . 
Child Protection Restoration and Penalties Enhancement Act of 1990, which banned possession of three or more images of child pornography. ${ }^{31}$

The advent of computer technology led to congressional concerns that existing legislation was out of date. In 1996, Congress expanded the definition of child pornography to encompass images that "[are] or appear[] to be, of a minor engaging in sexually explicit conduct." ${ }^{2}$ The Supreme Court struck down the ban on virtual child pornography because production of virtual child pornography did not abuse actual children. ${ }^{33}$ Congress responded with the 2003 PROTECT Act which, among other things, outlawed computer-generated

${ }^{31}$ S. Res. 3266, 101st Cong. (1990) (enacted as 18 U.S.C. $\$ 2252$ (2012)). Subsequent legislation banned possessing any images but created an affirmative defense for possession of less than three images when the defendant took steps to destroy the images or reported them to the authorities. 18 U.S.C. $\$ 2252 \mathrm{~A}(\mathrm{~d})$.

${ }^{32} 18$ U.S.C. $\$ 2256(8)(B)$ (2012) (emphasis added) (repealed 2003). Congress's ban on pornographic images of such virtual children was based on congressional findings of compelling state interests in protecting actual children from all child pornography, whether depicting real or virtual children. "The legislative history of the CPPA was premised on thirteen findings, including that pedophiles use images of child pornography to seduce actual children to engage in sexual conduct by reducing their inhibitions and desensitizing them." Rogers, supra note 13, at 328; see Child Pornography Prevention Act of 1996, Pub. L. No. 104-208, §121, 110 Stat. 3009-26, 3009-26-3009-27 (1996). Additionally, Congress found that both real and virtual child pornography whetted the appetite of molesters by fueling their fantasies and stimulating their desire to molest an actual child. $\S 121(1), 110$ Stat. at 3009-26-3009-27. Congress found further that the child pornography prosecutions would be increasingly difficult as images of virtual children become indistinguishable from actual victims of child pornography. See id. §121(1)(5)-(9). Second, it included as child pornography those materials that are "advertised, promoted, presented, described, or distributed in such a manner that conveys the impression that the material is or contains a visual depiction of a minor engaging in sexually explicit conduct." 18 U.S.C. § 2256(8)(D).

${ }^{33}$ Ashcroft v. Free Speech Coal., 535 U.S. 234, 256 (2002). The majority also rejected the government's indirect harm arguments. It ruled that the risks of virtual pornography whetting the appetite of child molesters or being shown by molesters to seduce children were too remote to support an abridgement of constitutionally protected speech. Id. at 253-54. In addition, the majority disagreed with the government's position that prohibiting virtual pornography is necessary to dry up the market for actual child pornography because they are part of the same market. Id. at 254-55. It noted the reverse-that allowing virtual pornography could in fact protect children by drying up the market of actual child pornography. The majority also upheld challenges to the CPPA's pandering section that prohibited materials that "convey[ed] the impression" that they were of a minor engaged in sexually explicit conduct. $I d$. at $255-56$. The Court noted that the provision prohibited possession of a sexually explicit film containing no minors merely because it was promoted as containing minors. Id. at 257. 
pornography that is "indistinguishable" from a real depiction, and created a five-year minimum sentence for transporting, distributing, or receiving child pornography. ${ }^{34}$ Part of the PROTECT Act included a new pandering provision with the same statutory sentence rules as the possession offense. ${ }^{35}$ Accordingly, even if images of child pornography are computergenerated, the speech offering or seeking them can be proscribed. ${ }^{36}$ Further acknowledging the impact of technology, in 2008, Congress expanded the ban on possession to include "access[ing] with intent to view" online images of child pornography after defendants had successfully argued they did not possess images unwittingly stored in their computers. ${ }^{37}$

\section{Sentencing History}

Parallel to congressional and judicial actions on child pornography offenses were the development of the Guidelines. Congress included mandatory minimums and maximums in many of the child pornography laws ${ }^{38}$ and directed the Sentencing Commission to establish Guidelines to implement the Sentencing Reform Act of 1984, which created the mandatory sentencing Guidelines. ${ }^{39}$ The Guidelines were meant to limit

${ }^{34}$ See Prosecutorial Remedies and Other Tools To End the Exploitation of Children Today Act of 2003 (PROTECT Act), Pub. L. No. 108-21, §§ 103(b)(C), 103(b)(E), 502(a)(1), 117 Stat. 650, 653, 678. The constitutionality of the "indistinguishable" language is untested.

${ }^{35} 18$ U.S.C. $\& 2252 \mathrm{~A}(\mathrm{a})(3)(\mathrm{B})$ (punishing a person who knowingly "advertises, promotes, presents, distributes, or solicits" child pornography). The Supreme Court upheld the constitutionality of the pandering provision and ruled that offers to engage in illegal activity were excluded from First Amendment protection. See United States v. Williams, 553 U.S. 285, 298-99 (2008).

${ }^{36}$ See generally Rogers, supra note 13.

${ }^{37} 18$ U.S.C. \$ 2252A(a)(5)(B). See generally Ty E. Howard, Don't Cache Out Your Case: Prosecuting Child Pornography Possession Laws Based on Images Located in Temporary Internet Files, 19 BERKELEY TECH. L.J. 1227 (2004).

${ }_{38}$ See, e.g., 18 U.S.C. $\$ 2252$ (b).

${ }^{39}$ Sentencing Reform Act of 1984 , Pub. L. No. 98-473, § 212(a)(2), 98 Stat. 1837, 1987-88 (1984) (codified as amended at 18 U.S.C. $\$ 3551$ (a) (2012)). See generally 2009 COMMISSION REPORT, supra note 3 . To do so, the Guidelines are structured so that each offense has a base offense level, which is then adjusted up or down by applying special offense characteristics. For example, the current base level for receiving child pornography is twenty-two; special offense characteristics include adding two levels if the images involved a child under twelve years old, four levels if the images portrayed sadistic behavior, and two levels for use of a computer; decreases by two levels are made if the defendant did not intend to distribute the material. See U.S. SENTENCING GUIDELINES MANUAL § 2G2.2 (2013); ORIN S. KERR, 
judicial discretion, provide for more uniformity in sentences, and reflect the purposes of punishing those who commit federal offenses. ${ }^{40}$ From the outset, the Commission labeled transporting, receiving, or distributing offenses as "trafficking" in child pornography. ${ }^{41}$

In a foreshadowing of current sentencing controversies, when possession was federally outlawed in 1991, the Commission amended the Guidelines by moving the receipt offense to the new possession guideline because it determined that "receipt is a logical predicate to possession." ${ }^{22}$ This change lasted less than one month because of strong congressional objection to the reduced penalty for receiving child pornography. ${ }^{43}$ The Commission continued to recognize the overlap between possession and receipt but separate Guidelines existed for trafficking offenses and possession offenses until 2004, when the Commission finally consolidated them. ${ }^{44}$ As discussed below, the consolidation of sentencing criteria without changes in offense categories only served to worsen sentencing controversies. ${ }^{45}$

COMPUTER CRIME LAW 278-79 (2d ed. 2009). The court can then make additional upward or downward modifications based on the specific circumstances of the defendant, the crime, or the victim. For example, if the defendant accepts responsibility for his actions, the offense level is decreased by two levels. See U.S. SENTENCING GUIDELINES MANUAL $\S 3 E 1.1$ (2013). With that final offense level calculation, the defendant's criminal history is considered and categorized. The Guidelines then provide a sentencing table that assigns a sentencing range. For example, in the previous example of a defendant receiving child pornography, if the defendant's final offense level is twenty-six, and he has no prior offenses so that his criminal history category is $I$, the Sentencing Table would call for a sentencing range of sixty-three to seventy-eight months. KERR, supra.

${ }_{40}$ See, e.g., 18 U.S.C. \$ 3553(a)(2) (2012); 2009 COMMISSION REPORT, supra note 3 , at $1 \mathrm{n} .2$. The four punishment rationales can be summarized as retribution, deterrence, incapacitation, and rehabilitation.

${ }^{41}$ See 2009 COMMISSION REPORT, supra note 3, at 14 (using trafficking to refer to the $\$ 2252$ crimes of transporting, receiving, and distributing child pornography). Initially, there were only two offense characteristic increase triggers: minor under twelve years old and distribution based on retail value. Id. at 12, 17; see also infra notes 160-82 and accompanying text (discussing the significance of the distribution enhancement).

422009 COMMISION REPORT, supra note 3, at 19.

${ }^{43}$ Id. at $19-22$.

44 Id. at 42-43. With the consolidation, the Commission added a two-level decrease if defendant's conduct was limited to receipt without intent to distribute. $I d$. at 48 . It did so specifically to ameliorate the disproportionality in sentences that the mandatory minimum was apt to create because it found that simple receipt was very similar to simple possession cases. Id.

${ }_{45}$ See infra Part III. 
Over the years, the Commission added numerous offense enhancements based on what it assessed to be aggravating factors, such as depicting prepubescent children ${ }^{46}$ or sadomasochistic attacks on children. ${ }^{47}$ While some enhancements were made after the Commission conducted a detailed study of empirical data, other enhancements resulted solely from congressional directive. The most controversial today are discussed below.

\section{Current Sentencing Controversy}

A chorus of scholars and judges have criticized the Guidelines as being more the product of public hysteria over child pornographers rather than being tied to a rational assessment of the goals of punishment. ${ }^{48}$ A leading critic of the current sentencing regime, Troy Stabenow, noted in his widelycited report, "The flaw with U.S.S.G. $§ 2$ G2.2 today is that a common, first time offender can chart at the statutory maximum, regardless of Acceptance of Responsibility and Criminal History." ${ }^{49}$ He outlined how the Commission increased the Guidelines based on congressional directives, such as the PROTECT Act's mandate of five-year minimums for trafficking offenses, rather than on empirical studies. ${ }^{50}$

For example, at the same time Congress made its failed attempt to ban computer-generated child pornography in 1996, it also directed the Sentencing Commission to increase sentences

${ }^{46}$ See U.S. Sentencing Guidelines Manual $\$ 2$ G2.2(b)(2) (2013) (adding twolevel enhancement).

${ }^{47}$ See id. \$ 2G2.2(b)(4) (adding four-level enhancement).

48 See, e.g., STABENOW, supra note 1, at 38; Jelani Jefferson Exum, Making the Punishment Fit the (Computer) Crime: Rebooting Notions of Possession for the Federal Sentencing of Child Pornography Offenses, 16 RICH. J.L. \& TECH. 8, 23-24 (2010); Carissa Byrne Hessick, Disentangling Child Pornography from Child Sex Abuse, 88 WASH. U. L. REV. 853, 865 (2011); Arlen Specter \& Linda Dale Hoffa, $A$ Quiet but Growing Judicial Rebellion Against Harsh Sentences for Child Pornography Offenses-Should the Laws Be Changed?, 35 CHAMPION 12, 13 (2011); see Melissa Hamilton, The Efficacy of Severe Child Pornography Sentencing: Empirical Validity or Political Rhetoric?, 22 STAN. L. \& POL'Y REV. 545, 560-61 (2011).

${ }^{49}$ STABENOW, supra note 1, at 26. A Westlaw search conducted on February 13, 2012 showed sixteen federal circuit court and twenty-three district court citations to the report.

${ }^{50}$ STABENOW, supra note 1, at 21. 
whenever a computer was used in child pornography offenses. ${ }^{51}$ It did so but cautioned such a broad application did not adequately differentiate between computer users, who, in 1996, could range from a simple downloader to a "large-scale, commercial pornographer[] ... who [could] upload, send or post illegal images." ${ }^{2}$

The Commission's promise to monitor the array of computer usage is all the more necessary today because computer technology has fundamentally altered the child pornography landscape. While only twenty-eight percent of defendants used a computer to commit child pornography offenses in 1995, by 2008 , ninety-six percent of defendants used one, and today, that number is most likely one hundred percent. ${ }^{53}$ This ubiquitous use is at the heart of the criticism of the enhancement. ${ }^{54}$ More significantly, the abilities the Commission ascribed only to sophisticated commercial operators, such as posting and uploading, can be performed by anyone today on a personal computer or tablet. Thus, the enhancement is flawed because the very nature of computer capabilities make the trafficker and purveyor distinction meaningless.

Another enhancement that has garnered extensive criticism is for the number of images possessed. ${ }^{55}$ First added in 2003, this enhancement did not have the benefit of empirical study or the standard notice and public comment period. ${ }^{56}$ Because computer technology allows individual to gather hundreds of images with the click of a mouse, some have criticized this enhancement as

51 2009 COMMISSION REPORT, supra note 3, at 26, 30. The congressional directive was contained in the Sex Crimes Against Children Prevention Act of 1995. Id. at 26.

52 U.S. SENTENCING COMM'N, SEX OfFENSES AGAINST CHILDREN: Findings AND RECOMmENDATIONS REgaRding FeDERAL PENALTIES 28-29 (1996), available at http://www.ussc.gov/Legislative_and_Public_Affairs/Congressional_Testimony_and_ Reports/Sex_Offense_Topics/199606_RtC_Sex_Crimes_Against_Children/199606_Rt C_SCAC.pdf.

${ }^{53}$ STABENOW, supra note 1, at 16; 2009 COMMISSION REPORT, supra note 3, at 30 n.148.

${ }_{54}$ See, e.g., STABENow, supra note 1, at 15-16. See generally Exum, supra note 48; Hessick, supra note 48.

${ }_{55}$ Ian N. Friedman \& Kristina W. Supler, Child Pornography Sentencing: The Road Here and the Road Ahead, 21 FED. SENT'G REP. 83, 85 (2008).

${ }^{56}$ STABENOW, supra note 1, at 23-24; 2009 COMMISSION REPORT, supra note 3, at $39 \mathrm{n} .190$. The effective date of the enhancement was in November 2004. See 2012 COMMISSION REPORT, supra note 3 , at 140. 
inconsequential in assessing blameworthiness. ${ }^{57}$ Professor Douglas Berman has echoed Stabenow's findings and has testified that sentencing enhancements such as use of a computer "[are] irrational because logically and factually, the characteristics are simply not genuine aggravating factors. Rather, they are inherent in just about any downloading offense." ${ }^{58}$

Other scholars criticize the sentences as based upon a faulty premise that possession of child pornography is as bad or worse than the child abuse that created it. ${ }^{59}$ They assert this parity fails to recognize the derivative nature of the child pornography offenses in that images are unlawful only because they are recording and then spreading images of actual abuse. ${ }^{60}$ Critics further claim that part of the increase is based on an unproven preventative rationale that possessors of child pornography are more likely to abuse children. ${ }^{61}$ As part of its review of child pornography offenses, the Sentencing Commission examined a number of studies and concluded that while general recidivism rates for downstream users of pornography were similar to that of all federal offenders, the rate of sexual recidivism was less than commonly believed. ${ }^{62}$ Yet, it found also that as many as thirty-eight percent of downstream users had prior criminal sexually dangerous behavior. ${ }^{63}$

In addition to scholarly criticism, surveys of district court judges conducted by the Commission in 2009 show that seventy percent believed the Guideline range for possession was too high; sixty-nine percent thought the range for receipt was too high; and thirty percent believed the range for distribution was too

${ }^{57}$ See, e.g., United States v. Hanson, 561 F. Supp. 2d 1004, 1010 (E.D. Wis. 2008). See generally STABENOW, supra note 1, at 21; Friedman \& Supler, supra note 55 .

${ }^{58}$ United States v. Grober, 595 F. Supp. 2d 382, 397 (D.N.J. 2008), affd, 624 F.3d 592 (3d Cir. 2010).

${ }^{59}$ Adler, supra note 14 , at 985 ("Child pornography law conflates act and image[s]."); Hessick, supra note 48, at 864-65. But see New York v. Ferber, 458 U.S. 747, 759-60 n.10 (1982).

60 See, e.g., Hessick, supra note 48 , at $865,867-68$.

61 See Hessick, supra note 48 , at $870-71$.

622012 COMMISSION REPORT, supra note 3 , at 306-10. It found a $30 \%$ rate of general recidivism, but only a $7.4 \%$ rate of sexual recidivism. Id. at 310 .

${ }^{63}$ Id. at 205. 
high. ${ }^{64}$ Circuit courts have also expressed reservations about the Guideline ranges. For example, the Second Circuit, in United States $v$. Dorvee, found that a 240-month sentence for distribution of child pornography was substantively unreasonable. ${ }^{65}$ It was troubled that the Guidelines for trafficking offenses were not based on empirical data, but rather on congressional directive. ${ }^{66}$

There are courts and scholars who support the Guidelines. ${ }^{67}$ For example, in testimony before the Sentencing Commission, Ernie Allen, President of the National Center for Missing and Exploited Children, explained that, as with other illegal contraband, child pornography needs to be stopped at the point of production and at the point of distribution and possession. ${ }^{68} \mathrm{He}$ pointed out that the Supreme Court has found a causal link between the demand for images and the possession and distribution of the images. ${ }^{69}$ Some have discounted the oft-cited Stabenow report as fundamentally flawed. ${ }^{70}$ For example, one district court judge noted Stabenow fails to identify the characteristics of the "average offender" who charts at the statutory maximum, but when one does so, it is a person that has "more than 600 images of prepubescent child pornography containing sadistic and masochistic images."71

${ }^{64}$ United States v. Grober, 624 F.3d 592, 606-07 (3d Cir. 2010) (citing U.S. SENTENCING COMM'N, RESUlTS OF SURVEY OF UNITED STATES DisTRICT JUDGES JANUARY 2010 THROUGH MARCH 2010 (2010), available at http://www.ussc.gov/ Research_and_Statistics/Research_Projects/Surveys/20100608_Judge_Survey.pdf).

${ }^{65} 616$ F.3d 174, 176 (2d Cir. 2010).

${ }^{66} \mathrm{Id}$. at 184 . It also found that the district court made procedural errors in calculating the sentence. Id. at 181-82.

${ }^{67}$ See, e.g., United States v. Phillips, No. 5:09CR534, 2010 WL 3219530 , at *1 (N.D. Ohio Alig. 10, 2010), affd, 455 F. App'x 624 (6th Cir. 2012); United States v. Cunningham, 680 F. Supp. 2d 844, 848-49 (N.D. Ohio 2010) (criticizing the Stabenow report), affd, 669 F.3d 723 (6th Cir. 2012); United States v. Fiorella, 602 F. Supp. 2d 1057, 1074, 1076 (N.D. Iowa 2009), affd sub nom. United States v. Shuler 598 F.3d 444 (8th Cir. 2010). See generally Exum, supra note 48.

${ }_{68}$ See Ernie Allen, President \& CEO, Nat'l Ctr. for Missing \& Exploited Children, Statement at the United States Sentencing Commission Regional Hearing on the 25th Anniversary of the Passage of the Sentencing Reform Act of 1984 (Oct. 20, 2009), available at http://www.ussc.gov/Legislative_and_Public_Affairs/Public_ Hearings_and_Meetings/20091020-21/Allen_testimony.pdf.

${ }^{69}$ Id. (citing New York v. Ferber, 458 U.S. 747, 759-60, n.10 (1982); Osborne v. Ohio, 495 U.S. 103, 109-10 (1990)).

${ }^{70}$ See, e.g., Cunningham, 680 F. Supp. $2 \mathrm{~d}$ at 852.

${ }^{71}$ Id. (internal quotation marks ommitted). 
It is telling that the Commission itself has criticized the direction Congress was taking. With the Sentencing Commission's call for public hearings on child pornography sentences, even the Justice Department agreed that sentencing enhancements based on the use of a computer and the number of images involved in a crime need to be reassessed. ${ }^{72}$ In its 2012 report, the Commission recommended the guidelines be revised to better measure culpability. ${ }^{73}$ For example, it agreed that the number of images per se was an "outmoded measure[]" of an offender's culpability; ${ }^{74}$ instead, it suggested a new measure that would focus on whether the offender engaged in online child pornography communities. ${ }^{75}$

Both sides make some sound arguments. There is validity to critics' arguments that derivative harm is typically less severe than direct harm. ${ }^{76}$ Yet they ignore that downstream users inflict independent psychological and dignitary harm. ${ }^{77}$ They may, in fact, be inflicting more harm than the producer of the image. Take, for example, a recent case in which an elementary school principal pled guilty to producing child pornography after he was caught surreptitiously recording boys' genitals while they were in the bathroom. ${ }^{78}$ Here, the harm suffered by the victims

${ }^{72}$ Letter from Jonathan J. Wroblewski, Dir., Office of Policy and Legislation, U.S. Dep't of Justice, to Chief Judge William K. Sessions III, U.S. Sentencing Comm'n 6 (June 28, 2010), available at http://sentencing.typepad.com/files/annual_ letter_2010_final_062810.pdf.

We believe the Commission should complete its review of the sentencing guidelines applicable to child exploitation crimes and prepare a report to Congress that might include recommendations for reforming the current child exploitation guidelines. The goal of any such reform would be to update the guidelines to address changing technology and realities surrounding these offenses, improve the consistency of sentences across child exploitation crimes, and ensure that the sentences for certain child Id. exploitation offenses adequately reflect the seriousness of the crimes.

${ }^{73} 2012$ COMMISSION REPORT, supra note 3, at 320-25.

${ }^{74} \mathrm{Id}$. at 321.

${ }^{75} \mathrm{Id}$. at $312-14$.

${ }^{76}$ Some disagree with these arguments. See Hessick, supra note 48, at 866 (citing critics).

${ }_{77}$ See supra notes $179,183$.

${ }^{78}$ Warren Richey, Child Pornography: Former Elementary-School Principal Gets 30 Years, CHRISTIAN SCI. MONITOR (Nov. 22, 2011), http://www.csmonitor.com/USA/ Justice/2011/1122/Child-pornography-Former-elementary-school-prinicipal-gets-30years. The FBI also found 32,000 images and over 12,000 videos of child pornography in his home, mostly obtained via the Internet. One might question whether the display was the "lascivious exhibition of the genitals" as required to 
was the embarrassment and distress of knowing the images were being circulated; they were not physically abused in the creation of them. Thus, we cannot say that harm inflicted by downstream users is less severe than harm inflicted by the producer of the images; a more nuanced approach that focuses on case specifics would be a better measure of harm.

The danger, however, of the intensity of the criticism of current sentences is that it has caused some to dismiss the premise that any harm has occurred. Many defendants claim possession is a "victimless" crime ${ }^{79}$ and while some lower courts agree, more reasoned courts have soundly rejected the notion that derivative use of child pornography is victimless. ${ }^{80}$ On the other hand, mulish support of the current sentencing regime in face of the mounting criticism of the Guidelines risks continued judicial nullification and randomized sentences. While Congress has sought to acknowledge the impact of technology on child pornography offenses, it has done so only by expanding the range of prohibited activities. ${ }^{81}$ It would be wise for Congress to also see technology as a limiting force in that the labels no longer define distinct behaviors, and therefore, the differential punishment scheme is increasingly devoid of rationale.

When we add to the sentencing controversy the new problem of how technology has conflated the offenses, we are left with a situation in dire need of reform. Essential to the solution is an understanding of the technological changes to the manner in which the child pornography crimes are being committed. The next Part traces these changes.

qualify as child pornography, 18 U.S.C. $\S 2256(2012)$, as it appears the boys were merely urinating in the bathroom. See United States v. Johnson, 639 F.3d 433, 43940 (8th Cir. 2011); United States v. Kemmerling, 285 F.3d 644, 645-46 (8th Cir. 2002); United States v. Dost, 636 F. Supp. 828, 832 (S.D. Cal. 1986), affd sub nom. United States v. Wiegand, 812 F.2d 1239 (9th Cir. 1987).

${ }^{79}$ See, e.g., United States v. D'Andrea, 473 F.3d 859, 865 (8th Cir. 2007); United States v. Rogers, 423 F.3d 823, 828 (8th Cir. 2005); State v. Berger, 134 P.3d 378, 386 (Ariz. 2006).

${ }_{80}$ See, e.g., United States v. Goff, 501 F.3d 250, 259 (3d Cir. 2007) (criticizing the district court's reasoning that a possession offense had no real victim); United States v. Cunningham, 680 F. Supp. 2d 844, 863-64 (N.D. Ohio 2010) (criticizing courts that see possession as a victimless crime).

${ }^{81}$ See 18 U.S.C. $\$ 2251$ (2012). 


\section{ThE GROWTH OF TECHNOLOGY}

As child pornography legislation developed over time, so did computer technology. The late 1970s and early 1980s saw the first spread of computers from isolated government and industrial usage to everyday personal usage..$^{82}$ Concomitantly, connectivity between computers was evolving. In the $1970 \mathrm{~s}$, computer engineers at research institutions throughout the United States began to link their computers together using telecommunications technology. The first networking card was created in 1973, allowing data transfer between connected computers. ${ }^{83}$ In time, the network, originally limited to academic and military institutions, spread and became known as the Internet. ${ }^{84}$

As computers were linked, file-sharing and online discussions were becoming increasingly popular. The first Internet discussion system, "Usenet," was developed in $1979 .{ }^{85}$ Its main purpose was the exchange of text-based messages, but

${ }^{82}$ See M. Scott Boone, The Past, Present, and Future of Computing and Its Impact on Digital Rights Management, $2008 \mathrm{MICH}$. ST. L. REV. 413, 416-18; see also Rebecca Blain, Evolution of Technology: The History of Computers, ARTICLES FACTORY, http://www.articlesfactory.com/articles/computers/the-evolutionof-technology-the-history-of-computers.html (last visited Mar. 2, 2014). The same year, Microsoft released the MS-DOS operating system, which was easy to operate. Id.

${ }^{83}$ Blain, supra note 82.

${ }^{84}$ Exhibits: Internet History 1970's, COMPUTER HISTORY MUSEUM, http://www.computerhistory.org/internet_history/internet_history_70s.html (last visited Mar. 2, 2014). The Advanced Research Projects Agency Network (ARPANET) was the world's first operational packet switching network and the core network of a set that came to compose the global Internet. The network was funded by United States Department of Defense for use by its projects at universities and research laboratories. With packet switching, a data system could use one communications link to communicate with more than one machine by collecting data into datagrams and transmitting these as packets onto the attached network link, whenever the link is not in use. Thus, not only could the link be shared, much as a single post box can be used to post letters to different destinations, but each packet could be routed independently of other packets. ARPANET-The First Internet, LIVING INTERNET, http://www.livinginternet.com/i/ii_arpanet.htm (last visited Mar. 2, 2014).

${ }^{85}$ See generally John L. Sullivan III, Note, Federal Courts Act as a Toll Booth to the Information Super Highway-Are Internet Restrictions Too High of a Price To Pay?, 44 NEw ENG. L. REv. 935 (2010). Usenet was originally written by a computer scientist at UNC to help communicate with Duke. COMPUTER HISTORY MUSEUM, supra note 84 . 
through attachments, it allowed users to encode files and distribute them to participating subscribers of Usenet newsgroups. ${ }^{86}$

Between 1979 and the mid-1990s, file-sharing was done through Usenet and bulletin board systems ("BBS"). ${ }^{87}$ Thousands of BBSs sprang up, creating active virtual communities. The "alt" hierarchy enabled the Usenet community to exercise freedom of speech by allowing anyone to create a group, such as alt.sex. ${ }^{88}$ Bulletin boards and Usenet eventually became obsolete as the Internet grew in popularity. ${ }^{89}$

In the 1990s, the tandem spread of applications like e-mail and the World Wide Web and the development of fast networking technologies like Ethernet ${ }^{90}$ saw computer networking become commonplace. ${ }^{91}$ The number of computers that are networked has grown explosively, from one million in $1992^{92}$ to over two billion by $2012 .{ }^{93}$ A very large proportion of personal computers regularly connect to the Internet to communicate and receive information. "Wireless" networking, which uses mobile phone networks, has meant that networking is becoming increasingly pervasive. ${ }^{94}$

${ }^{86}$ See Paul K. Ohm, Comment, On Regulating the Internet: Usenet, A Case Study, 46 UCLA L. REV. 1941, 1945-49 (1999).

87 See U.S. Gen. ACCOUNTING OfFICE, File-Sharing Programs: PeER-TO-PeER Networks PROVIDE READY ACCESS TO CHILD PORNOGRAPHY 6 (2003), available at http://www.gao.gov/new.items/d03351.pdf.

${ }_{88}$ Brian Reid, Alt Hierarchy History, LIVING INTERNET, http://www.livinginternet.com/u/ui_alt.htm (last visited Mar. 2, 2014).

89 See Sascha Segan, R.I.P Usernet: 1980-2008, PCMAG (July 31, 2008), www.pcmag.com/article2/0,2817,2326849,00.asp.

${ }_{90}$ John E. George \& Paul F. Kolesar, 10-Gigabit Ethernet Development for LAN Cabling Systems Well Underway, LIGHTWAVE (Dec. 1, 1999), http://www.light waveonline.com/articles/print/volume-16/issue-13/special-report/10-gigabit-ethernetdevelopment-for-lan-cabling-systems-well-underway-53490282.html. Ethernet is computer connectivity hardware that was developed by Xerox Parc, a research and development company. Edward L. Rubin, Computer Languages as Networks and Power Structures: Governing the Development of XML, 53 SMU L. REV. 1447, 1450 (2000).

${ }_{91}$ Mark Ward, How the Web Went World Wide, BBC NEWS (Aug. 3, 2006, 2:26 PM), http://newsvote.bbc.co.uk/mpapps/pagetools/print/news.bbc.co.uk/2/hi/tech nology/5242252.stm.

${ }_{92}$ COMPUTER HISTORY MUSEUM, supra note 84.

${ }_{93}$ Internet Usage Statistics: The Internet Big Picture, INTERNET WORLD STATS, http://www.internetworldstats.com/stats.htm (last updated Feb. 18, 2014).

94 See AARON SMITH, PEW INTERNET \& AM. LIFE PROJECT, MOBILE ACCESS 2010 2 (2010), available at $\mathrm{http} / / / \mathrm{www}$.pewinternet.org/files/old-media/Files/Reports/2010/ PIP_Mobile_Access_2010.pdf. 
While file-sharing was initially done through Usenet and Bulletin Boards, in 1999, Napster was released. ${ }^{95}$ Napster was a centralized system that indexed and stored music files that users of Napster made available on their computers for others to download. ${ }^{96}$ Files were transferred directly between users after authorization by Napster. ${ }^{97}$ It became extremely popular, and in 2001, Napster was sued by several recording companies. Napster lost in court against these companies and was eventually shut down. ${ }^{98}$

The next technological milestone was the development of decentralized file-sharing systems. ${ }^{99}$ The decentralized systems allow users to directly connect to each other's files, rather than going through a central index site. ${ }^{100}$ In 2001, Kazaa was released, with users mainly exchanging music files and other file types, such as videos, applications, and documents, over the Internet. ${ }^{101}$ Until its decline in 2004, Kazaa was the most popular file-sharing program in the world. ${ }^{102}$ As with Napster, it faced, and lost, numerous copyright infringement suits, until it declined in use and popularity. ${ }^{103}$

95 Spencer E. Ante et al., Inside Napster, BUSINESWEEK, Aug. 14, 2000, at 112, 114-15; M. Eric Johnson et al., The Evolution of the Peer-to-Peer File Sharing Industry and the Security Risks for Users, PROCEEDINGS OF THE 41ST HAW. INT'L CONFERENCE ON SYS. SCIS. 2 (2008), available at http://www.computer.org/csdl/ proceedings/hicss/2008/3075/00/30750383.pdf.

${ }_{96}$ A \& M Records, Inc. v. Napster, Inc., 114 F. Supp. 2d 896, 905 (N.D. Cal. 2000), affd in part, rev'd in part, 239 F.3d 1004 (9th Cir. 2001); see Karl Taro Greenfeld, Meet the Napster, TIME (Oct. 2, 2000), http://www.time.com/time/ magazine/article/0,9171,998068,00.html.

${ }_{97}$ A \& M Records, 114 F. Supp. 2d at 905.

98 Raymond Shih Ray Ku, The Creative Destruction of Copyright: Napster and the New Economics of Digital Technology, 69 U. CHI. L. REV. 263, 287-89 (2002); A \& $M$ Records, 114 F. Supp. $2 d$ at 927.

${ }_{99}$ See Johnson et al., supra note 95, at 1-2.

100 Napster's Sons: Singing a Different Tune?, BLOOMBERGBusINESSWEEK (Feb. 20, 2002), http://www.businessweek.com/stories/2002-02-20/napsters-sons-singing-adifferent-tune.

${ }^{101}$ See generally Richard Swope, Comment, Peer-to-Peer File Sharing and Copyright Infringement: Danger Ahead for Individuals Sharing Files on the Internet, 44 SANTA CLARA L. REV. 861, 875-88 (2004).

${ }_{102}$ Lance D. Clouse, Note, Virtual Border Customs: Prevention of International Online Music Piracy Within the Ever-Evolving Technological Landscape, 38 VAL. U. L. REV. 109, 122 n.63 (2003).

${ }^{103}$ See, e.g., Sony BMG Music Entm't v. Tenenbaum, 660 F.3d 487, 492-93, 515 (1st Cir. 2011); Eric Pfanner, Record and Movie Industries Reach a Settlement with Kazaa, N.Y. TiMES (July 28, 2006), http://www.nytimes.com/2006/07/28/technology/ 28kazaa.html?_r=0. 
New iterations of file-sharing networks, such as Limewire and BitTorrent, continue to allow no-cost, decentralized, peer-topeer file-sharing. ${ }^{104}$ Furthermore, file-sharing software evolved, so that computer users no longer had to install and configure sophisticated multiple file-sharing programs. ${ }^{105}$ Today, peer-topeer members need only download the compatible software from the Internet to become part of the network and be able to download digital files from other members of that network. ${ }^{106}$ They can also upload or post their files onto the network. ${ }^{107}$

A crucial aspect of peer-to-peer file-sharing is that the default setting for these networks is that downloaded files are placed in the user's "shared" folder, which allows others in the network to access the files. ${ }^{108}$ A user must affirmatively change his network setting to disable this sharing feature. ${ }^{109}$ The network is designed to encourage sharing by providing faster downloading if the user allows sharing. ${ }^{110}$ As the Internet has grown, so too has online child pornography. ${ }^{111}$ By 2005, child pornography over the Internet was a 3 billion dollar-a-year industry, consisting of over 4.2 million pornographic websites and approximately 372 million pornographic pages. ${ }^{112}$ The file-

${ }^{104}$ See Metro-Goldwyn-Mayer Studios Inc. v. Grokster, Ltd., 545 U.S. 913, 91920 (2005). In 2010, the recording industry obtained a permanent injunction against Limewire, shutting down its operation. See Arista Records LLC v. Lime Wire LLC, No. 06 Civ. 05936 (KMW), 2010 WL 4256219 (S.D.N.Y. Oct. 26, 2010) (proposed consent injunction). Shortly thereafter, unnamed developers released a new version entitled "Limewire Pirate Edition." See Ethan Smith, LimeWire Disavows New 'Pirate Edition', WaLL ST. J. (Nov. 11, 2010), http://online.wsj.com/article/SB1000 1424052748704804504575606862080016220.html.

105 Andrew Eichner, File Sharing: A Tool For Innovation, or a Criminal Instrument?, B.C. INTELL. PROP. \& TECH. F. (Sept. 2011), http://bciptf.org/wpcontent/uploads/2011/09/Andrew_Eichner_Note_File_Sharing_EICedits-finaledit.pdf.

${ }^{106}$ United States v. C.R., 792 F. Supp. 2d 343, 352 (E.D.N.Y. 2011).

${ }^{107} I d$.

${ }^{108}$ See, e.g., United States v. Layton, 564 F.3d 330, 335 (4th Cir. 2009); United States v. Carani, 492 F.3d 867, 875-76 (7th Cir. 2007); United States v. Griffin, 482 F.3d 1008, 1013 (8th Cir. 2007).

${ }^{109}$ See Carani, 492 F.3d at 869.

110 United States v. Geiner, 498 F.3d 1104, 1110-11 (10th Cir. 2007).

${ }^{111}$ See U.S. GEN. ACCOUNTING OFFICE, supra note 87, at 11, 13; see also U.S. DEP'T OF JUSTICE, THE NATIONAL STRATEGY FOR CHILD EXPLOITATION PREVENTION AND INTERDICTION: A REPORT TO CONGRESS 11 (2010), available at http://www.justice.gov/psc/docs/natstrategyreport.pdf (listing internet distribution channels).

${ }_{112}$ Women's Services \& Resources, BRIGHAM Young UNIV., Pornography, https://wsr.byu.edu/pornographystats (last visited Mar. 2, 2014). 
sharing network Gnutella has reported receiving 116,000 requests for child pornography in $2010 .{ }^{113}$ The ability to seek, download, and share files has completely changed the landscape for many industries, notably in the legitimate entertainment world. It has had the same dramatic impact in the child pornography arena.

The newest technology is cloud computing where files are stored in a shared pool of computer resources on the Internet, accessible from any computer. ${ }^{114}$ Users do not download and install applications on their own device or computer; all processing and storage is maintained by the cloud server. ${ }^{115}$ The latest commercial uses promote file storage and access. For example, a person may store files from his computer onto a cloud service provider, such as Dropbox..$^{116}$ The cloud system allows him to access his files from any computer by logging onto his cloud server. ${ }^{117}$ A cloud user may permit shared access to his files by designating users. ${ }^{118}$ Thus, similar to peer-to-peer networks, once a person allows access to his files, others may see them at any time. Unlike peer-to-peer networks, private cloud services require that a person designate who may have shared access. ${ }^{119}$

The cloud is just the latest battleground between law enforcement and child pornographers. The ability of child pornographers to use cloud computing for their wares has already been recognized. While some cloud providers are employing filtering techniques to suppress access to illegal

113 Exum, supra note 48, at 6; Pornography Industry Is Larger than the Revenues of the Top Technology, CY TALK BLOG (Jan. 1, 2010), http://blog.cy talk.com/2010/01/web-porn-revenue/.

114 See PETER MELL \& Timothy GRANCE, NAT'L InST.OF StandaRDS \& TECH., U.S. DEP'T OF COMMERCE, THE NIST DEFINITION OF ClOUD COMPUTING 2 (2011), available at http://csrc.nist.gov/publications/nistpubs/800-145/SP800-145.pdf; see also Cloud Computing: Clash of the Clouds, ECONOMIST (Oct. 15, 2009), http://www.economist.com/node/14637206?story_id=14637206.

115 See Cloud Computing: Clash of the Clouds, supra note 114.

116 Claire Cain Miller, Dropbox Bids To Find Entry in Businesses, N.Y. TIMES, Oct. 28, 2011, at B10.

117 See MELL \& GRANCE, supra note 114.

118 See id. at 3.

119 See id. 
images, there is a growing concern the cloud will provide deeper cover for pornographers. ${ }^{120}$ At the same time, cloud technology is beginning to raise possession and distribution questions. ${ }^{121}$

\section{THE LINES BLUR}

As file-sharing networks have proliferated, participants in the child pornography industry can no longer be defined by terms suited for a bricks-and-mortar world rather than a virtual world. We need to consider more fundamentally whether the problem is not just the piecemeal growth of offenses and enhancements, but whether the activities prohibited no longer have meaningful distinctions in the Internet age.

In the late 1970s when investigative reporters first exposed the child pornography market, it was clear who fell into the categories of transporters, distributors, and receivers (possession was not yet a crime). ${ }^{122}$ For example, the defendant in New York $v$. Ferber was the owner of an adult bookstore and knowingly sold films of underage boys masturbating. ${ }^{123}$ Once sold, those films were distributed and were no longer available for Ferber to resell. ${ }^{124}$ In contrast, take the person today who uploads a child pornography video to a peer-to-peer network and then leaves his file open. The video is never depleted; even if someone downloads it, the original is still available for further downloads. As the following discussion explores, the ramifications of this new technology are causing a collapse of easily definable offenses and a swell of fresh defense challenges.

\section{A. Receiving vs. Possessing}

Let us compare the defendant in Osborne $v$. Ohio ${ }^{125}$ to a contemporary possessor. Clyde Osborne was convicted of violating an Ohio statute that barred the possession of child pornography after police found four photographs of child

120 See Rob Gillen, Digital Forensics and the Cloud, FEDScoop (Jan. 17, 2011, 4:21 PM), http:/fedscoop.com/digital-forensics-and-the-cloud/; Martin Kaste, A Click Away: Preventing Online Child Porn Viewing, NPR (Aug. 31, 2010, 4:12 PM), http://www.npr.org/templates/story/story.php?storyId=129526579 (discussing filtering by internet service providers and search engines).

121 See infra notes 213-15 and accompanying text.

122 FINAL REPORT, supra note 4, at 603-04.

123458 U.S. 747, 751-52 (1982).

124 See id.

125495 U.S. 103 (1990). 
pornography in a desk drawer in the bedroom of his house. ${ }^{126}$ The appellant testified a friend brought the pictures to his home. ${ }^{127}$ It appears Osborne was charged only with the possession offense. ${ }^{128}$ Contrast Osborne with the defendant in United States $v$. Davenport, in which government agents found hundreds of images and videos of child pornography on the defendant's computer. ${ }^{129}$ The defendant was indicted on one count of receiving child pornography and on one count of possessing child pornography. ${ }^{130}$ He pled guilty and was sentenced to seventy-eight months in prison for each count, to run concurrently. ${ }^{131}$

On appeal of the district court's denial of his motion to withdraw his guilty plea, the defendant argued the sentence on both possession and receipt violated his Fifth Amendment double jeopardy right because the two statutory provisions proscribe the same conduct. ${ }^{132}$ As the defendant claimed, "It is impossible to 'receive' something without, at least at the very instant of 'receipt,' also 'possessing' it." ${ }^{133}$ The Ninth Circuit conducted a Blockberger analysis ${ }^{134}$ test and found that the receipt provision did not require proof of any additional elements beyond those required by the possession provision, and therefore, the

126 Id. at 139.

127 Id.

$128 \mathrm{Id}$. at $106-07$.

129519 F.3d 940, 972 (9th Cir. 2008).

$130 I d$.

$131 \mathrm{Id}$.

${ }^{132}$ Id. at 942-43. The Fifth Amendment's Double Jeopardy Clause guarantees that no person shall "be subject for the same offence to be twice put in jeopardy of life or limb." U.S. CONST. amend. V.

${ }^{133}$ Davenport, 519 F.3d at 943.

134 Blockburger v. United States, 284 U.S. 299, 304 (1932). The Blockburger Court stated that if "the same act or transaction constitutes a violation of two distinct statutory provisions, the test to be applied to determine whether there are two offenses or only one, is whether each provision requires proof of a fact which the other does not." Id. In determining whether two statutory provisions are punishing the same conduct, the courts first look to congressional intent. Absent clear intent to punish the defendant under two provisions, it is presumed that the legislature does not intend to impose two punishments for the same offense. See Rutledge v. United States, 517 U.S. 292, 297 (1996). Nevertheless, the presumption against allowing multiple punishments for the same crime may be overcome if there is a clear indication of legislative intent to allow courts to impose them. See Missouri v. Hunter, 459 U.S. 359, 368-69 (1983); Albernaz v. United States, 450 U.S. 333, 344 (1981); United States v. Bobb, 577 F.3d 1366, 1371 (11th Cir. 2009). 
government could not charge defendant with both offenses. ${ }^{135}$ The court acknowledged that prior to 1998, when Congress changed the requisite number of images for a possession charge from three or more images to any number of images, prosecution for violating both provisions was permissible because of the variance in the number of images needed for prosecution of receipt versus possession. ${ }^{136}$ The court reasoned that the older statutory language would allow for multiple convictions, but the amended language made the possession crime fall in as a lesserincluded crime of the receipt of child pornography. ${ }^{137}$

Other courts have agreed with Davenport's reasoning that the prohibition against double jeopardy bars multiplicitous charges of receipt and possession when a person downloads child pornography from the Internet. ${ }^{138}$ The remedy is to vacate the lesser offense, ${ }^{139}$ which still highlights a difficulty with the present statutory scheme-the receipt charge that remains has a mandatory five-year minimum sentence. ${ }^{140}$ Nevertheless, many courts have distinguished the Davenport line of cases and have

${ }^{135}$ Davenport, 519 F.3d at 947 . The receipt statute requires that pornographic material be "shipped or transported in ... interstate ... commerce by any means, including by computer," while the possession law states the pornography need only be "produced using materials that have been... shipped or transported in ... interstate . . commerce." Compare 18 U.S.C. $\$ 2252 \mathrm{~A}(\mathrm{a})(2)(\mathrm{A})$ (2012) with $\S 2252 \mathrm{~A}(\mathrm{a})(5)(\mathrm{B})$. The Davenport court found that because possession's nexus requirement can be met in one of two ways and receipt's nexus requirement is one of those two ways, possession is a lesser included offense of receipt. Davenport, 519 F.3d at $944-45$.

${ }^{136}$ Davenport, 519 F.3d at 946-47; see supra Part I.C. In a change that was meant to demonstrate a "zero tolerance" policy toward child pornographers, Congress amended the possession offense in 1998 to ban possession of even one image, whereas previous legislation limited the offense to three or more images. See 18 U.S.C. $\$ 2252 \mathrm{~A}(\mathrm{a})(5)(B)$. Instead it gave defendants an affirmative defense if they possessed fewer than three images. Id. $\$ 2252 \mathrm{~A}(\mathrm{~d})$.

${ }^{137}$ Davenport, 519 F.3d at 944-45. The court did recognize that an affirmative defense was only applicable to the possession provision but stated affirmative defenses are not considered elements of the crime for Blockburger purposes. Accord United States v. Miller, 527 F.3d 54, 72 (3d Cir. 2008).

${ }^{138}$ See, e.g., United States v. Brobst, 558 F.3d 982, 1000 (9th Cir. 2009); Bobb, 577 F.3d at 1374; Miller, 527 F.3d at 71; United States v. Giberson, 527 F.3d 882, 891 (9th Cir. 2008); United States v. Schaff, 838 F. Supp. 2d 1376, 1377 (S.D. Ga. 2011); United States v. Cunningham, No. 07-0298, 2010 WL 3809853 , at *2 (W.D. Pa. Sept. 22, 2010); United States v. Pomarico, No. 06 CR 113(RJD), $2010 \mathrm{WL}$ 4608423 , at *1 (E.D.N.Y. Nov. 1, 2010); see also United States v. Polouizzi, 564 F.3d 142, 154 (2d Cir. 2009) (dicta supporting Davenport reasoning).

${ }_{139}$ See, e.g., Schaff, 838 F. Supp. 2d at 1380-81; Cunningham, 2010 WL 3809853 , at *1; Pomarico, $2010 \mathrm{WL} 4608423$, at *2.

140 See 18 U.S.C. \& 2252A(b)(1). 
upheld convictions for both receipt and possession when the government asserts that its charges are different for image downloads. For example, in United States $v$. Bobb, the defendant's convictions and sentences were based on activities that occurred on two different dates. ${ }^{141}$ The evidence at trial established the defendant received child pornography by downloading files from a pornographic website, and on another date, he possessed over 6,000 additional images. ${ }^{142}$ Accordingly, the Eleventh Circuit, while agreeing with the Davenport line of reasoning, upheld the defendant's convictions, finding that the government introduced evidence sufficient to convict him of distinct offenses. ${ }^{143}$

With defendants using computers to obtain quantities of images via the Internet, it appears quite easy for the government to fashion a case in a manner to avoid double jeopardy violations by basing the receipt count on different images than the possession count. ${ }^{144}$ Yet, it is questionable whether such action is appropriate when the statutes themselves no longer reflect clear divisions of activity. It is outmoded to find, as some courts have, that those who traffic in child pornography by receiving it "are more directly tied to the market for such products" and the abuse of children necessary for that market than are possessors. ${ }^{145}$ When the person engages in one act ${ }^{146}$ and thereby commits two crimes, the stated rationale for highly divergent punishments is dubious.

141577 F.3d at $1369-70$.

${ }^{142} I d$. at $1368-69$.

${ }^{143} I d$. at 1375 . When multiple images are found, courts have held that these images may not be the basis of multiple counts of the same offense. See, e.g., Polouizzi, 564 F.3d at 155. But see United States v. Flyer, No. CR 05-1049 TUC-FRZ, 2006 WL 2590459, at *5 (D. Ariz. Sept. 7, 2006). Therefore, the 6,000 images resulted in one count of possession. The number of images, however, is a sentencing enhancement. See supra notes 56-58 and accompanying text.

${ }_{144}$ See, e.g., Polouizzi, 564 F.3d at 147-48; United States v. Burgess, No. 1:09CR17, 2010 WL 2219335, at * 1 (W.D.N.C. May 28, 2010); cf. United States. v. Irving, 554 F.3d 64, 79 (2d Cir. 2009) (rejecting double jeopardy issue sua sponte).

${ }^{145}$ See United States v. Myers, 355 F.3d 1040, 1042-43 (7th Cir. 2004); accord United States v. Davenport, 519 F.3d 940, 951 (9th Cir. 2008) (Graber, J., dissenting) ("[T] $]$ he statutory provisions are directed toward different harms."); United States v. Grosenheider, 200 F.3d 321, 332-33 (5th Cir. 2000).

${ }^{146}$ It is, of course, possible to inadvertently receive child pornography and then consciously choose to keep it. In that instance, the person would be guilty only of possession. See United States v. Watzman, 486 F.3d 1004, 1009-10 (7th Cir. 2007). 
If we look at these cases in the context of the development of the child pornography laws, we can see the genesis of the original distinctions since possession was not initially covered and receipt was initially thought of as part of the commercial trade; these variables have disappeared. The Commission recognized this as early as 1990 when it tried to join the receiving and possessing offense Guidelines, a move roundly rejected by Congress. ${ }^{147}$ Additionally, in its 1996 Report to Congress, the Commission detailed that some courts were sentencing receipt cases as possession cases because there was little difference in the perceived seriousness of the offenses. ${ }^{148}$ The offense Guidelines were eventually combined, but this created a new problemcertain enhancements previously limited to the trafficking offenses now apply to simple possession cases. ${ }^{149}$

When a person can receive and possess images with a few clicks of a mouse, the overlap in the offenses is obvious. ${ }^{150} \mathrm{~A}$ child is harmed because the image is circulated, but the offender cannot be said to be more entrenched in the market by his receipt than by his possession of the image.

\section{B. Distributing vs. Possessing}

The conflation of offenses is further complicated because distribution is both an offense and a sentencing enhancement to receipt and possession charges.

\section{Distribution as an Offense}

Peer-to-peer file-sharing, only popularized in the last few years, has dramatically altered the collecting of child pornography. It has also led to defendants being charged and

${ }^{147}$ When possession was federally outlawed in 1991, Congress directed the Commission to establish sentencing Guidelines for the new possession offense. 2009 COMMISSION REPORT, supra note 3, at 19. Initially, the Commission amended the Guidelines by moving the receipt offense to the new possession guideline because it determined that "receipt is a logical predicate to possession." Id. It distinguished possession and simple receipt from receipt with intent to traffic. Id. This change lasted less than one month because of strong congressional objection to the reduced penalty for receiving child pornography. Id. at 20-22. Thus, separate Guidelines existed for trafficking offenses and possession offenses until 2004, when the Commission consolidated them. Id. at 42 .

1482009 COMMISSION REPORT, supra note 3, at 29-30.

149 Id. at 49; see supra notes 44-45 and accompanying text.

150 See 2012 COMMISSION REPORT, supra note 3, at 326-27 (recommending that the sentences for receipt and possession be aligned). 
convicted of both distributing and possessing child pornography. For example, in United States $v$. Schaffer, a defendant downloaded images and videos from a peer-to-peer network and stored them in a shared folder on his computer, which was accessible to others. ${ }^{151}$ Arguing that he merely left open his shared file, the defendant sought to have his conviction for distribution set aside. ${ }^{152}$ The Tenth Circuit rejected his contention, noting that he freely allowed access to his computerized stash of images and videos, knowing that others could download his stash. ${ }^{153}$ The court made an analogy to a selfserve gas station reasoning that the gas station owner who advertises his product need not actively pump gas to be in the business of distributing it. ${ }^{154}$ Similarly, it reasoned that the knowing passive distribution of child pornography from a shared network was sufficient to sustain the conviction. ${ }^{155}$

Recently, some courts have recognized the overlap between offenses caused by technology. The Third Circuit, in United States $v$. Grober, affirmed a sentence that substantially deviated from the Guidelines in a case where the defendant traded via the Internet a number of images of child pornography. ${ }^{156}$ Charged with transporting, receiving, and possessing child pornography, the defendant pled guilty. ${ }^{157}$ The district court ruled this was a "typical downloading" case, and sentenced him to sixty months imprisonment-the mandatory minimum-rather than the Guideline amount of 235 to 293 months. ${ }^{158}$ Rejecting the government's appeal of the sentence, the Third Circuit found that the deviation was appropriate because it agreed that the case "center[ed] on personal possession of illicit images obtained on

${ }_{151} 472$ F.3d 1219, 1222 (10th Cir. 2007).

${ }^{162}$ Id. at 1223.

${ }^{153} I d$.

${ }^{154}$ Id. at $1223-24$.

${ }^{165}$ Id.; accord United States v. Collins, 642 F.3d 654, 656-57 (8th Cir. 2011); United States v. Layton, 564 F.3d 330, 335 (4th Cir. 2009); United States v. Darway, 255 F. App'x 68, 70-72 (6th Cir. 2007); United States v. Geiner, 498 F.3d 1104, 1109-10 (10th Cir. 2007); United States v. Carani, 492 F.3d 867, 875-76 (7th Cir. 2007); United States v. Griffin, 482 F.3d 1008, 1011-12 (8th Cir. 2007); United States v. Mathenia, 409 F.3d 1289, 1290 (11th Cir. 2005); United States v. Rogers, 666 F. Supp. 2d 148, 150-52 (D. Me. 2009); United States v. Abraham, No. CR NO. 05-344, 2006 WL 3052702, at *8 (W.D. Pa. Oct. 24, 2006).

${ }^{156}$ See 624 F.3d 592, 595, 611 (3d Cir. 2010).

${ }^{157}$ Id. at 595-96.

${ }^{158} \mathrm{Id}$. at 596, 598-99. 
line, and involving no production or distribution other than noncommercial bartering," notwithstanding the defendant's guilty plea on the transporting and receiving counts. ${ }^{159}$

\section{Distribution as Sentencing Factor}

The category collapse among the child pornography offenses is striking when we look at the courts' struggle with the meaning of the enhancement variables, particularly when images are distributed through file-sharing programs. From the outset, the Guidelines included an increase to the base level applicable to trafficking offenses if an image was distributed. ${ }^{160}$ It later distinguished between distributing in exchange for money or other "things of value" and distributing without any gain. ${ }^{161}$ Courts have interpreted the phrase "thing of value" to mean pornographic images a person actively trades over a peer-to-peer network. ${ }^{162}$ Even if the person only downloads images, he can meet the "thing of value" distribution enhancement if he knows others have access to his images through the shared network. ${ }^{163}$ Merely getting faster download speeds, a crucial design function of a peer-to-peer network, also constitutes a "thing of value."164 Thus, a number of courts held that using a peer-to-peer network warrants a per se five-level distribution enhancement. ${ }^{165}$ Other courts apply only a lesser two-level enhancement when a defendant uses a peer-to-peer network. ${ }^{166}$ One court

159 Id. at $598 \mathrm{n} .1$.

160 See 2009 COMMISSION REPORT, supra note 3 , at 10.

161 See id. at 33-35 (internal quotation marks ommitted); see also U.S. SENTENCING GUIDELINES MANUAL § 2G2.2(b)(3) (2013). Distribution for pecuniary gain and for "receipt, or expectation of receipt, of a thing of value, but not for pecuniary gain" merits a five-level increase, and distribution for other reasons merits a two-level increase. Id. $\$ 2 \mathrm{G} 2.2(\mathrm{~b})(3)(\mathrm{B})$. The Guidelines also called for a fivelevel increase if the distribution was to a minor and a seven-level increase if it was to a minor with the intent to have the minor engage in prohibited sexual activity. Id. $\S 2 \mathrm{G} 2.2(\mathrm{~b})(3)$.

162 See, e.g., United States v. Griffin, 482 F.3d 1008, 1013 (8th Cir. 2007) (internal quotation marks ommitted); United States v. McVey, 476 F. Supp. 2d 560, 563 (E.D. Va. 2007).

${ }_{163}$ See United States v. Durham, 618 F.3d 921, 925 (8th Cir. 2010).

164 See id.

165 See id.

166 See, e.g., United States v. Dodd, 598 F.3d 449, 451-52 (8th Cir. 2010); United States v. Estey, 595 F.3d 836, 844 (8th Cir. 2010). 
acknowledged either enhancement could apply-a troubling overlap because there appears to be no rhyme or reason to the choice. ${ }^{167}$

To rectify the problem, some courts have cut back on a per se approach and have ruled the issue should be decided on a caseby-case basis. ${ }^{168}$ This solution has created its own issues because courts have allowed the enhancement with little direct proof of knowing distribution. Some courts have inferred knowledge based on the level of sophistication of the computer user. ${ }^{169}$

Most troubling is judicial use of a "willful blindness" standard to impose the distribution enhancement. For example, in 2010, the Eighth Circuit upheld a finding that the defendant's conduct warranted a distribution enhancement when he downloaded images onto Limewire, a peer-to-peer program. ${ }^{170}$ The court rejected the defendant's contention that he did not know his computer was equipped to distribute. ${ }^{171}$ It reasoned that "the purpose of a file sharing program is to share, in other words, to distribute. Absent concrete evidence of ignoranceevidence that is needed because ignorance is entirely counterintuitive-a fact-finder may reasonably infer that the defendant knowingly employed a file sharing program for its intended purpose."172 The implications of this court's reasoning cannot be understated. A willful blindness standard could drastically increase a person's punishment and, in today's age, may impact every user of a peer-to-peer program. Furthermore, as new sharing platforms are created, more and more individuals will be sharing information, whether they are aware or not. ${ }^{173}$ Criminality of such conduct must depend on more than a legal tool such as willful blindness.

${ }^{167}$ See Estey, 595 F.3d at 843.

168 See id. at 843-44; Dodd, 598 F.3d at 451.

169 See, e.g., United States v. Bastian, 603 F.3d 460, 466 (8th Cir. 2010).

170 See Dodd, 598 F.3d at 451-52. As there was no evidence that defendant received anything of value to warrant the five-level enhancement, the government sought a two-level enhancement. Id. at 451.

${ }^{171}$ See id. at 451-52.

172 Id. at 452; accord United States v. Durham, 618 F.3d 921, 932 (8th Cir. 2010) (finding that defendant established actual ignorance); $c f$. United States v. DuFran, 430 F. App'x 855, 857-58 (11th Cir. 2011); United States v. Layton, 564 F.3d 330, 335 (4th Cir. 2009).

${ }^{173}$ See infra notes $213-17$ and accompanying text. 
Finally, courts are holding that defendants who use filesharing programs are ineligible for any decrease in the base level offense originally passed by the Commission for simple receipt offenses with no proof of distribution. ${ }^{174}$ For example, in 2011, the Seventh Circuit noted it would be frivolous for a defendant who used a file-sharing program to argue for a two-level decrease. ${ }^{175}$ As the use of peer-to-peer networks continues to grow, it will cause a de facto elimination of this decrease.

As courts increasingly differ on what actions qualify for upward and downward sentence adjustments when a person uses a peer-to-peer network to obtain child pornography, the courts' actions are in danger of appearing arbitrary. For example, when calculating the sentence for a person convicted of possession, receipt, and distribution of child pornography via a peer-to-peer network, the sentencing court would have to use different base levels for each offense, and, in addition to other enhancement calculations, decide the applicability of the distribution sentencing factor, with the following possibilities: decrease by two, increase by two, or increase by five. Such discretion is arbitrary when it is not based on a reasoned calculation of the harm a defendant has inflicted, but rather on outmoded categories of offenses.

\section{Transporting vs. Possessing}

Peer-to-peer file-sharing has also resulted in defendants being charged with transporting child pornography when they leave their network open. In a case virtually indistinguishable from Shaffer, ${ }^{176}$ prosecutors chose to charge a defendant with transporting child pornography rather than distributing it. ${ }^{177}$ The same use of a peer-to-peer network now exposes a defendant to charges of transporting, distributing, receiving, and possessing child pornography.

As technology evolves, so too should the law. We should not have de facto and unintentional changes in offenses and sentences. For example, when the Commission combined the trafficking and possessing Guidelines, it exposed possessors to distribution enhancements because of sharing networks. In

\footnotetext{
174 See 2009 COMMISSION REPORT, supra note 3, at 48.

175 United States v. Armes, 415 F. App'x 729, 730 (7th Cir. 2011).

176472 F.3d 1219 (10th Cir. 2007).

177 United States v. Schade, 318 F. App'x 91, 93 (3d Cir. 2009).
} 
addition, the same network use has essentially eliminated the two-level receiving decrease. As the Commission moves forward with its review, it must assess whether these changes were intentional and whether they result in appropriate sentences.

\section{RECOMMENDATIONS}

Political implications for members of Congress should they appear to be soft on child pornographers means statutory changes may be difficult to enact; nevertheless, these recommendations are made with a view of at least helping to shape a discussion of these issues. Employing a harm principle gives a starting point for addressing current offenses and sentencing controversies. As the landmark child pornography cases have stated repeatedly, users of child pornography cause the depicted child to be shamed and humiliated by the knowledge people are looking at the images of the child being abused. ${ }^{178}$

This humiliation is exacerbated by the Internet. As one court described, "[T]he child victims suffer not only from the initial physical sexual abuse of their tormentors, but also from the knowledge that their degradation will be repeatedly viewed electronically into near perpetuity by a large audience."179

When adult abuse survivors become aware that the images of them as children are circulating on the Internet, they become even more mistrustful of people and have more of a sense of helplessness and hopelessness. ${ }^{180}$ As one psychologist explained, "In childhood, they knew that they were physically invaded and they couldn't stop it. As adults, they know they're visually invaded and they can't stop it. ... So, knowing that [the images are] out there just deepens the pathology that they're already suffering from." ${ }^{\prime 81}$

Beyond psychological injury, a more fundamental harm is suffered. Even if the child was unaware the image was circulated, those who trade in and view child pornography harm

${ }^{178}$ See supra notes 16-19, 29 and accompanying text. Other harms are that users contribute to the market for child pornography that could lead to abuse of additional children, and that children can be "groomed" into permitting acts of abuse against them if they see images and perceive that the behavior is acceptable. See generally Rogers, supra note 13.

179 United States v. C.R., 792 F. Supp. 2d 343, 357 (E.D.N.Y. 2011); see also New York v. Ferber, 458 U.S. 747, 756-60 (1982).

${ }^{180}$ C.R., 792 F. Supp. 2 d at 382.

${ }^{181}$ Id. 
the child's inherent right not to be viewed in this fashion. There is harm each and every time an image is circulated. From where does this human dignity right derive? This right goes beyond tort theories on invasion of privacy. ${ }^{182}$ We can look to more analogous situations for answers.

\section{A. The Fundamental Harm in Images}

Images are so powerful that, in diverse settings, special rules apply to them. For example, the Geneva Convention requires that prisoners of war ("POWs") be treated humanely, and this includes banning photographs of them that subject them to humiliation or public curiosity. ${ }^{183}$ Some courts have construed the term "public curiosity" to ban photographs that are released for the purpose of humiliating those depicted. ${ }^{184}$ Under Articles 13 and 14 of the 1949 Geneva Conventions III Relative to the Treatment of Prisoners of War, POWs are also "entitled in all circumstances to respect for their persons and their honour."185 Even non-POWs, or so-called enemy combatants, are entitled to protection against "outrages upon personal dignity, in particular

${ }^{182}$ The issue of restitution to victims from pornographers under 18 U.S.C. $\$ 2259(\mathrm{~b})(1)(2012)$, the mandatory restitution statute, has been the subject of recent court decisions and has split circuit courts. Some circuit courts have held that possessors are too remote to be the proximate cause of a victim's injury and therefore no damages are recoverable. See, e.g., United States v. Aumais, 656 F.3d 147, 154-55 (2d Cir. 2011). Others have held that the restitution statute has only a limited proximity requirement. See, e.g., In re Amy Unknown, 636 F.3d 190, 198 (5th Cir. 2011), affd in part and vacated in part, 701 F.3d 749 (5th Cir. 2012). The impact of these cases on the current issue is doubtful as they deal with remuneration; criminal culpability dependent on outmoded statutory classifications raises wholly separate issues. While on the surface one might argue that if a possessor is not liable for damages, then he should not be criminally liable, the Supreme Court has long laid to rest the constitutionality of punishing possessors. See Osborne v. Ohio, 495 U.S. 103, 111-14 (1990). In fact, even in Aumais, the court upheld the possessor's sentence of 121 months. Aumais, 656 F.3d at $156-57$.

${ }_{183}$ Geneva Convention Relative to the Treatment of Prisoners of War art. 13, Aug. 12, 1949, 6 U.S.T. 3316, 75 U.N.T.S. 135; Geneva Convention Relative to the Protection of Civilian Persons in Time of War art. 27, Aug. 12, 1949, 6 U.S.T. 3516, 75 U.N.T.S. 287. See generally Robert Cryer, The Fine Art of Friendship: Jus In Bello in Afghanistan, 7 J. CONFLICT \& SECURITY L. 37, 73-76 (2002); Noel Whitty, Soldier Photography of Detainee Abuse in Iraq: Digital Technology, Human Rights and the Death of Baha Mousa, 10 HUM. RTS. L. REV. 689, 691 (2010).

${ }^{184}$ ACLU v. Dep't of Def., 543 F.3d 59, 90 (2d Cir. 2008), vacated on other grounds, 130 S. Ct. 777 (2009).

${ }^{185}$ Geneva Convention Relative to the Treatment of Prisoners of War, supra note 183 , art. 14 . 
humiliating and degrading treatment." 186 One need only think of the disgrace over the Abu Ghraib incident to see the impact of photographs. It was not just the humiliating treatment itself; it was the taking and dissemination of photographs of the humiliation that was contemptible. ${ }^{187}$ The same criticism was made following the release of photographs of Saddam Hussein after his capture. ${ }^{188}$

Death scene and autopsy photographs are also subject to dissemination restrictions. In National Archives and Records Administration $v$. Favish, ${ }^{189}$ the Supreme Court ruled that families are entitled to limit disclosure of death-scene images of their loved ones. ${ }^{190}$ The case involved death-scene photographs of Vincent Foster, Jr., deputy counsel to President Clinton, and the respondent's Freedom of Information Act ("FOIA") request for the photos. In denying the FOIA request, the Court noted FOIA Exemption 7(C) excuses from disclosure information compiled by law enforcement if its production "could reasonably be expected to constitute an unwarranted invasion of personal privacy." 191 Foster's sister explained her opposition to the release of the photos: "[I] was horrified and devastated by [a] photograph [already] leaked to the press. [E]very time I see it,... I have nightmares and heart-pounding insomnia as I visualize how he must have spent his last few minutes and seconds of his life."192 She opposed the disclosure of the disputed pictures because

186 Protocol Additional to the Geneva Conventions of 12 August 1949, and Relating to the Protection of Victims of International Armed Conflicts (Protocol I) art. 75(2)(b), June 8, 1977, 16 I.L.M. 1391, 1423. See generally Cryer, supra note 183.

187 See Cryer, supra note 183 , at $74 \mathrm{n} .200$ (“[T] he reference is, strictly speaking to the customary concomitant of art. 75, as the US is not bound by the Protocol, having signed, but not ratified it."); Pamela Hess, Geneva Convention Prohibits Filming POWs, UNITED PRESS INT'L (Mar. 23, 2003), http://www.upi.com/Business_ News/Security-Industry/2003/03/23/Geneva-Convention-prohibits-filming-POWs/ UPI-80261048460384/.

${ }^{188}$ Josh White \& Ellen Knickmeyer, U.S. Officials Condemn Hussein Photos; Investigation Begun After British Tabloid Publishes Pictures of Iraqi in Custody, WASH. POST, May 21, 2005, at A13.

189541 U.S. 157 (2004).

190 Clay Calvert, Salvaging Privacy \& Tranquility from the Wreckage: Images of Death, Emotions of Distress \& Remedies of Tort in the Age of the Internet, 2010 MICH. ST. L. REV. 311, 312; see also Favish, 541 U.S. at 170.

191 Favish, 541 U.S. at 160 (internal quotation marks omitted).

192 Id. at 167 (alterations in original) (citation omitted) (internal quotation marks omitted). 
"[u]ndoubtedly, the photographs would be placed on the Internet for world consumption" and would renew media interest in her brother's death. ${ }^{193}$

The Court agreed that FOIA exemption 7(C) extended beyond the person depicted to his family members and banned release of the images, unless the person requesting the information establishes a significant public interest in the information sufficient to override the family's privacy interest in the images. ${ }^{194}$ It found that the respondent failed to meet this burden. ${ }^{195}$ Tort law also limits dissemination of non-newsworthy death and autopsy images. ${ }^{196}$ They are deemed to be inherently humiliating and distressful for the family and can subject the releasers to damages. ${ }^{197}$

Other courts ban the release of private information even if identities are protected. In Northwestern Memorial Hospital $v$. Ashcroft, the government sought medical records of patients who received late-term abortions to aid the government's constitutional challenge to the Partial-Birth Abortion Act of 2003. ${ }^{198}$ In rejecting the government's demand, the Seventh Circuit ruled it would be an invasion of the privacy rights of anonymous patients. ${ }^{199}$ The court's reasoning is particularly relevant to the victims of child pornography:

Imagine if nude pictures of a woman, uploaded to the Internet without her consent though without identifying her by name, were downloaded in a foreign country by people who will never meet her. She would still feel that her privacy had been invaded. The revelation of the intimate details contained in the record of a late-term abortion may inflict a similar wound. ${ }^{200}$

Dissemination of images for no worthy purpose inflicts harm on the depicted person. The absolute lack of any worthy reason to trade in child pornography establishes the inherent harm to the dignity of the child depicted. The person inflicting the abuse captured in a pornographic image is obviously deserving of

\footnotetext{
${ }^{193}$ Id. (internal quotation marks omitted).

194 Id. at 172.

195 Id. at 175. See generally Calvert, supra note 190.

196 Calvert, supra note 190 , at 313.

${ }^{197}$ See, e.g., Catsouras v. Dep't of Cal. Highway Patrol, 104 Cal. Rptr. 3d 352, 357 (Ct. App. 2010), modified, 2010 Cal. App. LEXIS 253 (Ct. App. 2010).

198362 F.3d 923, 924 (7th Cir. 2004); see also 18 U.S.C. \$ 1531 (2012).

${ }^{199} \mathrm{Nw}$. Mem'l Hosp., 362 F.3d at 929.

200 Id.
} 
substantial punishment as a child molester. The producer of the image is guilty of documenting the infliction of sexual abuse. The harm that others further down the chain inflict lacks physicality, but they too inflict distinct, actual harm on the child whose image is disseminated and collected.

\section{B. Statutory and Guideline Changes}

Under current federal law, producers are punished separately and most severely. ${ }^{201}$ Others in the pornography network are differentiated by activity, ${ }^{202}$ and the law treats attempts to commit prohibited offenses equally to the completed offenses. $^{203}$ As explained in Part III, however, when a person uses file-sharing technology, the categories of prohibited activities involving child pornography no longer reflect crisply defined actions. Thus, transporters, distributors, and possessors often are one and the same, engaging in identical activity. We can define them as "traders."

In place of the current statutory scheme, a more valid delineation would be among producers, traders, and seekers of child pornography. Since it is the producer who usually inflicts the most harm, he should have the most severe sentence; traders also harm the child, but typically to a lesser degree because they are not involved in any direct sexual abuse of a child. One possibility is that all activities involving the trading of child pornography have the same statutory base sentence. This is in keeping with fundamental harm theory because the depicted children are damaged by any and all proliferation of their images. Starting at the same base level, the Commission could then establish enhancements or departures to distinguish among the traders and their individual culpability. For example, one suggestion is that the first person to upload images be punished more severely than later downloaders. ${ }^{204}$ Similarly, one who runs a chat room or bulletin board is more culpable than those who visit those sites.

${ }^{201} 18$ U.S.C. $\$ 2251$ (2012) (minimum fifteen year, maximum thirty year sentence).

202 Id. $\$ 2252 \mathrm{~A}$.

${ }^{203}$ Id. $\$ \S 2251(\mathrm{e}), 2252 \mathrm{~A}(\mathrm{~b})(1), 2252 \mathrm{~A}(\mathrm{~b})(2)$.

204 Exum, supra note 48, at 39. 
A caveat to placing all traders in the same base category is that it should not automatically increase sentences for possessors-which would occur if the current divisions between distributors, receivers, and possessors are made into one. Instead, Congress needs to reexamine the current mandatory sentence structure against the backdrop of the blurring of offenses that exists with current technology. ${ }^{205}$

Those who have not yet obtained images should be punished lesser still since they have not yet inflicted harm. ${ }^{206}$ This suggestion is in keeping with the basic tenet of attempt laws that do not punish attempts as severely as completed crimes. ${ }^{207}$ Thus, the statutes which now contain the same punishment for those attempting to commit child pornography could be parsed so the attempt is punished at a lower level. The attempts are more comparable to the child pornography crimes of pandering and belong more appropriately grouped together. ${ }^{208}$

As previously discussed in Part III, many scholars and judges have criticized the Guideline enhancement for number of images possessed. ${ }^{209}$ Troy Stabenow has argued that punishing a defendant based on the number of images he or she has accumulated is akin to punishing a habitual marijuana smoker for every marijuana cigarette he or she has smoked over the past several years. ${ }^{210}$ This analogy is wrong in that it does not acknowledge the offender has violated each child's right not to be viewed in a pornographic image. The collection continues to exist, unlike the dissipated marijuana, and the defendant who knowingly accesses large amounts of child pornography is harming large numbers of children. A better approach suggested by the Sentencing Commission would focus on the extent to which an offender is involved in online child pornography

${ }^{205}$ Even the Justice Department agrees. See Wroblewski, supra note 72, at 3-6.

${ }^{206}$ See generally Audrey Rogers, New Technology, Old Defenses: Internet Sting Operations and Attempt Liability, 38 U. RICH. L. REV. 477, 479-83 (2004).

${ }^{207}$ See generally GEORGe P. FleTCHER, RETHINKING CRIMINAL LAW 473-74 (2000); WAYNE R. LAFAVE, CRIMINAL LAW 646-47 (5th ed. 2010).

${ }^{208} 18$ U.S.C. $\S 2252 \mathrm{~A}(\mathrm{a})(3)(\mathrm{B})$. In keeping with the thesis of this Article, since the pandering offense is an inchoate crime, Congress should re-examine its sentence, which is currently a mandatory five-year minimum. $I d$. $\S 2252 \mathrm{~A}(\mathrm{~b})(1)$.

${ }^{209}$ See supra notes 56-58 and accompanying text.

210 Jesse P. Basbaum, Note, Inequitable Sentencing for Possession of Child Pornography: A Failure To Distinguish Voyeurs from Pederasts, 61 HASTINGS L.J. 1281, 1301 n.163 (2010) (describing a telephone Interview with Troy Stabenow, Assistant Federal Public Defender on January 13, 2010). 
communities. ${ }^{211}$ In addition, the use-of-computer enhancement does not adequately relate to the harm suffered by the child depicted and should be eliminated. ${ }^{212}$

The need to reform the laws becomes more urgent as technology continues its unabated growth. For example, cloud computing is becoming more and more popular. ${ }^{213}$ Shared file functions that are available may make cloud computing analogous to peer-to-peer networking, but on a much larger platform. Given this technology, a person who collects child pornography by storing it on a cloud server may also be a distributer of the image by virtue of the sharing function of his cloud files. ${ }^{214}$ Yet, since the images are stored on a remote server, some have questioned whether and who possesses them. ${ }^{215}$

Similarly, as wireless routers are now increasingly used to access the Internet, a person who fails to lock his router with a password could potentially be charged if his router is used by someone to transmit child pornography. ${ }^{216}$ The analogy would be to peer-to-peer file sharers who fail to opt out of the sharing function. Taken to its logical extreme, the same willful blindness standard the courts have used in the file-sharing cases could apply to owners of unprotected routers. ${ }^{217}$ Of course, there is a difference in that a third person is hacking into an unprotected wireless network, as opposed to being part of a file-sharing network, but one who knows and fails to protect his router from unauthorized access is leaving himself open to charges.

211 See supra text accompanying notes 73-75.

${ }^{212}$ See supra text accompanying note 77; supra note 178.

${ }^{213}$ See supra notes 114-16 and accompanying text.

${ }^{214}$ See Marc Jonathan Blitz, Stanley in Cyberspace: Why the Privacy Protection of the First Amendment Should Be More Like That of the Fourth, 62 HASTINGS L.J. $357,364(2010)$.

215 Id.

${ }^{216}$ See Jean-Loup Richet, FBI Child Porn Raid a Strong Argument for Locking Down WiFi Networks, INFO. SYSTEMS RES. BLOG (June 2, 2011), http://www.information-systems-research.com/blog/2011/06/02/fbi-child-porn-raid-astrong-argument-for-locking-down-wifi-networks. No charges were brought against the unwitting host. Id.

${ }^{217}$ Cf. Global-Tech Appliances, Inc. v. SEB S.A., 131 S.Ct. 2060, 2068-69 (2011) (discussing willful blindness standard applied in patent infringement case). There is a difference in that a person is hacking into an unprotected wireless network, as opposed to being part of a file-sharing network, but whether this is legally significant is untested as yet. 


\section{CONCLUSION}

Fears that the Internet would be a boon to child pornographers have been realized as the number of images permanently circulating in cyberspace has ballooned into the millions. Yet, to be effective in punishing this flood, the law must accurately delineate the culpable conduct. The divisions among traders of child pornography are no longer accurate; and, therefore, the differentials in punishment have lost their underpinnings. The current sentencing controversy surrounding child pornographers is merely the tip of the iceberg of the larger need to revamp the offenses themselves.

Optimally, Congress should revise the child pornography statutes to reflect technology; however, most likely this is politically unfeasible. Nevertheless, failure to act will allow the current debate to harden positions with negative consequences. Harsh sentences, such as life imprisonment for possession of child pornography, as one court imposed recently, are counterproductive to the ostensible rationale for punishment. ${ }^{218}$ Rather than deterring the prohibited activity, it causes some to question the validity of the offense itself or minimize its gravity. At the other extreme, to equate the harm inflicted by sexual predators in producing pornographic images of children, with that of downstream traders, is equally ineffective. The proposed framework, at the very least, may allow judges to properly tailor punishments and give the Commission guidance in revamping its Guidelines.

${ }^{218}$ Erica Goode, Life Sentence for Possession of Child Pornography Spurs Debate over Severity, N.Y. TIMES, Nov. 4, 2011, at A9. 